\title{
Manufacturing Enterprise Company: Integration of curriculum and industry
}

\author{
Scott Danielson, Russel Biekert, Alvin Post, Scott Almen, Norbert Richter \\ Arizona State University East / OmniMount Inc.
}

\begin{abstract}
Historically, Manufacturing Engineering Technology curricula offer courses on a semester basis with limited connections between subjects. Individual course requirements restrict student problem-solving experiences and students are often unable to synthesize material from different courses when solving multifaceted problems. This paper describes the Manufacturing Enterprise Company (MECO) and illustrates a sample project. MECO is a curriculum construct joining subject matter in multiple courses over a four-semester sequence by introducing a large problem to be solved by collaboration. Through this integration, the overall function of a manufacturing engineer is better understood by the students. The MECO construct puts course content with context, and infuses it with a problem-solving atmosphere requiring exercise of communications skills.
\end{abstract}

\section{Introduction}

It is often taken as conventional wisdom that today's students have difficulty cooperating, thinking critically, dealing with innovations, and skillfully solving problems. Unfortunately, faculty often fail to take the broad view of the educational process, too often falling into the mind set described below.

Faculty members pay attention to their individual courses, departments to their majors, and students to their choice of electives; but few persons, and sometimes none, pay attention to the overall enterprise ${ }^{1}$.

As early as 1935, a study for the National Personnel Service ranked methods and devices of instruction on the basis of effectiveness. Having two or more instructors responsible for class instruction and activity was among the top ranked methods for improving university classroom teaching ${ }^{2}$. Team teaching can also apply to a cluster course model where team teaching refers to faculty efforts coordinating separate courses in different content areas. Courses arranged in a cluster relate to a topic and develop different aspects of that topic. Collaboration through team teaching provides a method through which faculty can discuss ideas and concerns. Discussions of course content and perspectives nurture new ideas. Students reap benefits as well by seeing the "connectedness" of knowledge. 
Faculty collaboration in teaching affects not only the professors themselves, but also the students. Team teaching that brings diverse disciplinary perspectives to the study of a topic helps students gain an appreciation of the essential connectedness of all knowledge ${ }^{3}$.

In traditional practice, university education is based on individual accomplishment with narrow textbook problems. Understanding and application of typical industrial problems, in context, is often neither examined nor rewarded. Ann Bailey calls for rethinking of higher education methods and goals to empower students to "deliver the goods" under parameters reflecting industrial scenarios where due dates are key elements in the success of business ${ }^{4}$. In Planning $a$ Professional Curriculum, Fisher and Levene ${ }^{5}$ state:

If students are thrown into the problems of an area, to tackle these problems in a meaningful way they will want to learn the terms and facts, concepts, relationships and principles, that form the heart of the area currently under study (p.86).

The educational process, as with other processes, can be improved to better prepare students for production engineering and problem solving. Unfortunately, most university programs provide the basic knowledge of manufacturing engineering as disjointed material until some sort of capstone experience. Thus, the synthesis of information needed to solve most engineering problems from different courses can be difficult for students. The overall capability expected of the entry level-manufacturing engineer is not reinforced in the academic program because subject material is not coordinated across the curriculum. We believe entry-level manufacturing engineers would be better prepared if their undergraduate classes worked together in an integrated manner.

\section{The Manufacturing Enterprise Company (MECO)}

The MECO approach introduces an actual industrial project into the academic sequence every year. The project requires design or redesign, development and process planning, casting and $\mathrm{CNC}$ machining to create prototypes, and cell layout and group technology for production planning as it moves through various classes over the four semesters. Students in various manufacturing courses (see Table 1), usually in work teams, to advance the part from a design/redesign phase to finished production assembly and inspection (including statistical process analysis and charting). This analysis will involve process control charts and process variation charts to analyze the quality of the processes created by the classes for that product cycle. Sponsoring industry representatives interact with students throughout the project. Various design courses within, e.g., MET 331, Machine Design or MET 460, Manufacturing Capstone I, also can participate depending on the needs of the MECO project.

\section{Table 1}

Critical Manufacturing Courses in MECO

MET 341, Manufacturing Analysis

MET 443, CNC Machining

MET 401, Quality Assurance
MET 344, Casting and Forming

MET 444, Production Tooling 
The MECO product is produced over a four-semester cycle that begins in the fall semester; the semesters focus on design, development, pre-production prototype, and full production in sequence. New students are integrated into the project each semester as different junior and senior courses are involved and this makes good documentation and communication mandatory. Since industrial projects develop within a time frame, the experience of meeting deadlines and goals is integrated into the university environment. Students become increasingly aware of their contribution toward the overall goal.

A new cycle begins every year with the introduction of a new product, which parallels a commercial product manufactured by a local, cooperating company. The professor and students brainstorm new product ideas that must meet certain criteria, including but not limited to an appropriate level of complexity and producability within the university environment. Industry input is sought as appropraite. Seven specific criteria considered during this step are:

- Availability of process within the department

- Budget constraints

- Skill level of the students (keeping product features within student capacity)

- Process knowledge introduced prior to production

- Product features and characteristics requiring specific operations (outsourcing may be required)

- Challenging product and part design

- Industrial interest in the project

The new projects have to meet or exceed relevant industrial standards and incorporate new criteria developed from previous products. Industrial representatives interact with the students heavily during this phase.

Redesigning at least a portion of the part assembly for casting is considered important to MECO. In part, this bias is due to the belief that manufacturing students traditionally have a weakness in working with complex 3-D parts. For instance, molded parts in which a single part serves many functions in a product are not something often made while in school. Student projects frequently feature many relatively simple machined parts because the students are poorly equipped to think in terms of the more complex shapes and functions found in manufactured products. They rarely learn how to effectively combine part functions to reduce part count. Yet, another way to improve problem-solving skills with mechanical parts is to provide experience with additive manufacturing processes, such as casting, injection molding or rapid prototyping.

Once the students choose a design, they format and communicate that design with CAD drawings meeting industrial standards. These drawings communicate details of the product in a professional and effective manner. Drawing production introduces datum structures and industrial standards and forces greater rigor than is generally found in normal coursework. The professor and industy representatives review these prints, require changes, and students then document changes and distribute the initial and subsequent releases among MECO teams. This 
process illustrates the importance of proper revision and communication of product and process changes.

When students' projects require expert knowledge in specific design or manufacturing processes, coordination of industrial liaisons extends the capability and horizons of the student team. These liaisons contribute pertinent knowledge and ingenuity in specialty areas when classes fall short of providing requisite material.

\section{Example Projects}

The MECO concept has been used for multiple product cycles in the Manufacturing Engineering Technology program at Arizona State University. The first project started with a valve body produced by Allied Signal Aerospace (now Honeywell). Blueprints and mentors from Allied Signal provided the industry-based aspects of the course. The MECO students produced industrial quality drawings, removing the Allied Signal name and modifying materials and part tolerances to meet the ASU laboratory capabilities. Then the MECO students created molds and cast 20 parts for machining. Other classes wrote the process plans (routing), designed and built fixtures, and machined the final parts on a CNC-machining center. Furthermore, inspection and control charts were developed on a Mitutoyo Coordinate Measuring Machine (CMM) and quality assurance data was compiled.

Another, more current, MECO project was introduced in the spring semester of 2002. The product was the ARC frame for a CRT mounting system manufactured by OmniMount Inc. (Phoenix, Arizona). This product was first introduced to the students in MET 341, Manufacturing Analysis, and MET 344, Casting and Forming. This sequence is typical of most MECO projects because MET 341 students focus on the project the entire semester. This class is fundamental to the project as it embodies the bulk of the product specification and planning process.

In MET 341, Manufacturing Analysis, the following functions are completed. All work items are done by multiple student teams and all are judged by an industry team at the end of the course.

a) Product specification analysis is completed.

b) Product is re-designed to fit MECO capabilities while still maintaining OmniMount functionality.

c) CAD drawings are created and approved.

d) CAD drawings are distributed to students in Casting and Forming class.

e) A two-year plan is created for the product (Gantt Chart).

f) Process plans (methods, operations, and tooling) are created.

g) Manufacturing cell designs are created.

h) Manufacturing cells are simulated by senior students in the Simulation class (MET 415).

i) Complete cost analysis of the product cycle (manufacture and assembly) is created.

In MET 344, Casting and Forming, the following functions are completed by multiple student teams and reviewed by a team of industry professionals from the fields of casting and forming.

a) A casting drawing is created parts to be cast (the top clamp was sand cast).

b) A pattern for the sand casting is designed. 
c) A sand casting matchplate is fabricated.

d) Production plan for casting is created.

e) Casting cost analysis is completed.

f) A set of parts are cast and prepared for follow-on processing in other classes.

g) Forming dies are designed and approved (for specific parts that will be formed in the OmniMount assembly).

h) Forming dies are manufactured by the students.

i) Prototype parts are manufactured.

During the Fall Semester 2002, the OmniMount - MECO product was introduced in MET 443, the advanced CAD/CAM Machining course, and MET 444, Tool Design and Fabrication. In MET 444, the following functions were completed. Again, there were multiple student teams designing fixtures and these were judged at the end of the semester by an industry team.

a) Fixtures were designed to support machining the OmniMount top clamp on a HAAS CNC machining center.

b) The fixture drawings were submitted for approval before construction.

c) Completed fixtures were fabricated (to be used in MET 443- see below).

d) A cost analysis of each fixture was completed.

In MET 443, the following functions were completed.

a) Computer-numerical-control (CNC) programs were written to do the required machining steps on the cast OmniMount top clamp and other required parts.

b) Parts were machined to specification (using the drawings created in MET 341).

During the Spring Semester of 2003, a sampling of the completed parts will be given to the quality assurance class, MET 401. In MET 401, the machined OmniMount parts will be inspected on the Mitutoyo CMM and statistically analyzed (including CPK values), based on the original part documentation created in MET 341.

To continue the cycle, in the 2003 spring semester, a new product will be introduced. Typically, the same industry partner is used for two years in a row. Thus, an OmniMount product will be used again in this cycle. This product is called a "manipulator" and is used for new "thin" screen applications. The cycle will start again in MET 341 and MET 344.

\section{Conclusions}

Students involved in MECO face challenging production problems and often create innovative solutions. From design to inspection, students overcome the challenges of process planning, tooling, teamwork, communications, and planning. The manufacturing processes and philosophies students learn through MECO prepare them for the task of manufacturing production. MECO helps students to be able to function at higher efficiencies immediately upon entry to industrial practice.

In part, this is accomplished as MECO addresses many of the Society for Manufacturing Engineer's competency gaps ${ }^{6}$. Table 2 illustrates this by listing specific SME competency gaps and briefly describes how MECO addresses them. 
Table 2.

\section{SME Competency Gaps and MECO}

\begin{tabular}{|c|c|}
\hline GAP & APPROACH \\
\hline $\begin{array}{l}\text { Project Management } \\
\text { Skills }\end{array}$ & $\begin{array}{l}\text { Students participate in the entire } 2 \text {-year MECO product cycle. All MECO } \\
\text { courses have a project management component in their course content. }\end{array}$ \\
\hline $\begin{array}{l}\text { Oral \& Written } \\
\text { Communication Skills }\end{array}$ & $\begin{array}{l}\text { Students make presentations and submit written reports to MECO } \\
\text { management and to the managers or engineers from MECO-supporting } \\
\text { companies. All normal forms of product and manufacturing documentation } \\
\text { have to be written and submitted for review in the MECO cycle. }\end{array}$ \\
\hline $\begin{array}{l}\text { Specific Manufacturing } \\
\text { Processes Knowledge }\end{array}$ & $\begin{array}{l}\text { Students make decisions about design, materials, etc., based on the } \\
\text { manufacturing techniques and equipment they have chosen to use within } \\
\text { MECO. Ultimately, they will have to live with their decisions (or modify } \\
\text { them) as they produce MECO prototypes and first articles. As they do this, } \\
\text { they will gain hands-on experience with a range of current and emerging } \\
\text { manufacturing technologies. }\end{array}$ \\
\hline $\begin{array}{l}\text { Manufacturing Process } \\
\text { Control \& Quality } \\
\text { Assurance }\end{array}$ & $\begin{array}{l}\text { Students learn, practice and understand process control, process planning, } \\
\text { and statistical quality methods (SPC) in MET 341, Manufacturing Analysis } \\
\text { and MET 401, Quality Assurance. }\end{array}$ \\
\hline Manufacturing Systems & $\begin{array}{l}\text { Students gain experience with cellular design for manufacturing and } \\
\text { assembly and process flow analysis. }\end{array}$ \\
\hline Problem-Solving Skills & $\begin{array}{l}\text { Students must solve practical problems that emerge throughout the MECO } \\
\text { product cycle, and learn by experience how solutions to problems at one } \\
\text { stage affect the project at a later stage. All MECO courses use problem } \\
\text { solving as a method of instruction. }\end{array}$ \\
\hline Teamwork & $\begin{array}{l}\text { Students work in teams and interface with students in other classes } \\
\text { throughout the MECO project. Teamwork includes student teams, faculty } \\
\text { teams, and industry teams all working together toward a common goal. }\end{array}$ \\
\hline Material Selection \& Use & $\begin{array}{l}\text { Students understand materials selection and application in the early design } \\
\text { phase of the MECO project. A make-buy analysis determines which } \\
\text { components of the industrial products are to be manufactured in MECO. }\end{array}$ \\
\hline $\begin{array}{l}\text { Product/Process } \\
\text { Design }\end{array}$ & $\begin{array}{l}\text { Students design or redesign the MECO product, as well as the } \\
\text { manufacturing process for it, in the sequential series of courses in which } \\
\text { MECO is integrated. }\end{array}$ \\
\hline $\begin{array}{l}\text { Ability to work with } \\
\text { complex geometries and } \\
\text { parts }\end{array}$ & $\begin{array}{l}\text { Machining is very expensive, as processes go, and molding and casting can } \\
\text { often be much more economical, especially when several parts are combined } \\
\text { into one. Students typically design parts with very simple geometries } \\
\text { because the most common and accessible manufacturing process they are } \\
\text { exposed to is machining. They rarely develop adequate visualization skills } \\
\text { for complex 3-D shapes for this reason. MECO remedies this by giving } \\
\text { students opportunity to construct complex shapes using 3-D solid modeling } \\
\text { and the generation of casting models. }\end{array}$ \\
\hline
\end{tabular}

In addition, exposure to industrial involvement helps prepare students for the responsibilities of the professional manufacturing engineer. Students better understand the scope of work that engineers perform and begin to feel the sense of urgency that competitive industry faces. Thus, MECO helps establish student understanding of industrial expectations upon graduation.

The MECO format requires students to communicate within groups and to other classes to move the product through the cycle. In addition, students gain more practical experience with various 
manufacturing techniques. They gain the ability to think in terms of complex part geometries when needed and when appropriate and learn to use the evaluation tools of metrology and SPC in a practical setting as well.

The dynamic approach of product infusion removes stale textbook teaching and replaces it with more exciting engineering practice. Professors illustrate book knowledge and students then practice formulating solutions. As students provide answers to manufacturing problems, they become more confident in their abilities. Exposure to teaming environments and concurrent engineering contribute to increased student determination and conviction. Students gain meaningful experience to prepare them for future challenges.

\section{Bibliography}

1. Carnegie Foundation for the Advancement of Teaching. 1977. Missions of the College Curriculum. San Francisco: Jossey-Bass. p.10.

2. Reed, Anna. 1935. The Effective and the Ineffective College Teacher. New York: America Book Company.

3. Austin, A. \& Baldwin, R. 1991. Faculty Collaboration: Enhancing the Quality of Scholarship and Teaching. ASHE-ERIC Higher Education Report No. 7. Washington, DC: The George Washington University, School of Education and Human Development, p.43.

4. Wright, P. 1990. Industry and Higher Education. Bristol, PA.: Open University Press.

5. Fisher, L. \& Levene, C. 1989. Planning a Professional Curriculum. Calgary: University of Calgary Press.

6. SME, 2002. See http://www.sme.org.

\section{Biographical Information}

\section{SCOTT DANIELSON}

Scott Danielson is chair of the Mechanical \& Manufacturing Engineering Technology Department at Arizona State University East. His areas of interest are enhan cing student learning, manufacturing processes, and aircraft manufacturing and support. He and his colleagues have received grants from the NSF, the Bush Foundation, and the Society of Manufacturing Engineers.

\section{RUSSEL BIEKERT}

Russel Biekert is an associate professor in the Mechanical \& Manufacturing En gineering Technology Department at Arizona State University East. Before joining ASU East, he served as Vice President for Operations at Corning Gilbert. He is a past International Director of SME and a Fellow of SME. His areas of interest are manufacturing processes, manufacturing management, and laboratory teaching that replicates industry conditions.

\section{ALVIN POST}

Alvin Post is an assistant professor in the Mechanical \& Manufacturing Engineering Technology Department at Arizona State University East. Before joining ASU East, Dr. Post taught at McGill University in Canada and had a 19-year career at IBM as a designer. His areas of interest are machine design, applied engineering mathematics, and education. 
Session 2563

\section{SCOTT ALMEN}

Scott Almen is the Laboratory Manager for the Mechanical \& Manufacturing Engineering Technology Department at Arizona State University East. He has a degree in Mechanical En gineering Technology and manufacturing operations experience.

\section{NORBERT RICHTER}

Norbert Richter is the Chief Engineer of OmniMount Systems, Inc, and a Faculty Associate with Arizona State University. His graduate project organized, tracked, and documented the first two MECO projects in 1994 and 1995. His interests are in non-traditional manufacturing and design. 